\title{
1 Saving the world's ash forests calls for international cooperation now
}

2 Ash forests in North America and Eurasia are rapidly being lost to two invasive alien

species: Emerald Ash Borer and Chalara Ash Dieback Fungus. We assert here that better regulatory policy and science-based intervention can help slowing losses. To this end, we recommend an international consortium for co-ordinating science-based intervention.

Devrim Semizer-Cuming ${ }^{1,2 *}$, Konstantin V. Krutovsky ${ }^{1,3,4,5}$, Yuri N. Baranchikov ${ }^{6}$, Erik D. Kjær $^{2}$, Claire G. Williams ${ }^{7 *}$

${ }^{1}$ Department of Forest Genetics and Forest Tree Breeding, Georg-August University of Göttingen, Büsgenweg 2, 37077, Göttingen, Germany. ${ }^{2}$ Forest, Nature and Biomass, Department of Geosciences and Natural Resource Management, University of Copenhagen, Rolighedsvej 23, 1958 Frederiksberg, Copenhagen, Denmark. ${ }^{3}$ Laboratory of Population Genetics, Vavilov Institute of General Genetics, Russian Academy of Sciences, Moscow 119991, Russian Federation. ${ }^{4}$ Laboratory of Forest Genomics, Genome Research and Education Center, Siberian Federal University, Krasnoyarsk 660036, Russian Federation. ${ }^{5}$ Department of Ecosystem Science and Management, Texas A\&M University, College Station, TX 77843-2138, USA. ${ }^{6}$ Sukachev Institute of Forest FRC KSC of the Siberian Branch of the Russian Academy of Sciences, Krasnoyarsk, Russian Federation. ${ }^{7}$ Department of Environmental Sciences, American University, Washington D.C. 20016, USA.

\section{*Corresponding Authors:}

E-mail: dsemize@ forst.uni-goettingen.de, claire-williams@ fulbrightmail.org Title: 61 characters

Text Word Count: 2434

Table: 1; Figure: 1

References: 30

Keywords: Agrilus planipennis, Chalara Ash Dieback Fungus, Emerald Ash Borer, forest biodiversity, Hymenoscyphus fraxineus, species extinction 
Global losses of Fraxinus species can be traced to the Emerald Ash Borer (EAB), a woodboring beetle (Agrilus planipennis Fairmaire), and Chalara Ash Dieback Fungus (ADF), an Ascomycete fungus (Hymenoscyphus fraxineus (T. Kowalski) Baral, Queloz \& Hosoya), both of which are indigenous to Asia (Fig. 1). Losses to both harmful organisms may be abated with swift international cooperation using readily available resources. To illustrate this, we analyze the problem then examine policy solutions including harmonized phytosanitary regulations, best practices for detecting pathogen infection, and available research resources. These solutions, policy and scientific, are best co-ordinated by forming an international consortium. Ash forest losses in North America and Eurasia can be slowed with timely intervention.

Fig. 1 Ash (Fraxinus) species distribution and secondary ranges of two invaders, Emerald Ash

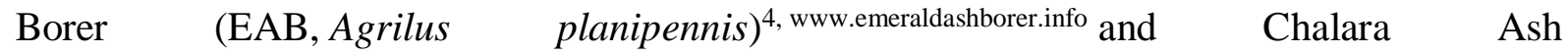
Dieback Fungus (ADF, Hymenoscyphus fraxineus) $)^{13,15}$ : (1) Distribution of Asian ash species with primary ranges of EAB and ADF; (2) Distribution of European and North American ash species; (3) Secondary range of EAB; (4) Secondary range of ADF. Distributions in Canada, Scandinavia and Spain are generated based on real observations, and in Russia and the US are based on administrative regions (districts and states) where $\mathrm{EAB}$ and ADF were found. Left photo (by Lene Rostgaard Nielsen) - Fruiting bodies of ADF observed in Denmark; Right photo (by Yuri Baranchikov) - EAB observed in Voronezh District, Russia.

\section{Problem analysis}

The world's 48 Fraxinus species in the Northern Hemisphere consist of large and small trees or shrubs (Table 1$)^{1}$. Among them, five species, namely white ash (Fraxinus americana), green ash $(F$. pennsylvanica $)$ and black ash ( F. nigra) of North America, common ash (F. excelsior) of Europe, and Manchurian ash (F. mandshurica) of northeast Asia are the most widely distributed and commercially important species. Ash species are also prized for ecological 
value, comprising over $20 \%$ of the urban tree species across the United States alone ${ }^{2}$, and thus are deemed essential for urban-coupled human-forest ecosystems. They serve as keystone species in a variety of forest ecosystems while providing food sources for wildlife.

In North America, ash forests are rapidly being lost to the exotic EAB, which dates back to the late $1990 s^{3}$. EAB spends most of its life cycle hidden under bark causing no visible symptoms ${ }^{4,5}$. Only a few beetles can rapidly infest an entire forest and kill trees within a few years $^{3}$. Total losses to date are roughly 689 million $\mathrm{m}^{3}$ volume for standing ash timber in the United States $^{[1]}$. EAB has since been detected in 35 States from the Atlantic coast westward to Colorado and in five Canadian Provinces: Ontario, Quebec, New Brunswick, Nova Scotia and Manitoba (www.emeraldashborer.info, accessed October 11, 2018). Estimated costs of ash losses in urban areas from EAB alone, including tree removal and replacements, are $\$ 7.6$ billion in Ohio and \$26 billion for Illinois, Indiana, Michigan and Wisconsin ${ }^{6}$. Annual damages from EAB have reached $\$ 38$ million for the federal government, $\$ 850$ million for local governments, $\$ 380$ million for residential property value loss and $\$ 60$ million for forest landowner timber sales $^{7}$. Thus, EAB is the most costly forest insect to have invaded the United States to date.

Human transport has been responsible for the beetle's trans-continental dispersal, occurring mainly via freight packing materials, lumber, firewood, live plants, and various manufactured wood articles 5 . EAB found in the North American ash forests originated in China's Hebei Province and nearby Tianjin City, indicating China's wood trade ${ }^{[2]}$ as the entry point of EAB into North America 9 .

In Europe, ADF, as the most acute forest pathogen problem at this time, is also thought to have been introduced from East Asia, particularly Japan and northeastern China ${ }^{10}$. It decimated F. excelsior since the early 1990s; millions of trees are now dying ${ }^{11}$. While ADF spores are

\footnotetext{
${ }^{[1]}$ Source: U.S. Forest Service Forest Inventory and Analysis Program 'EVALIDator'.

${ }^{[2]}$ Since the countries' participation to the World Trade Organization (WTO) in 2001, China has become highly important as a producer and a consumer of forest products, and is currently the largest producer and exporter of wood-based panels ${ }^{8}$.
} 
transported across landscapes, its dispersal is aided by the movement of nursery plants and possibly by movement of firewood and $\log \mathrm{s}^{11,12}$.

Russia is the first country to report losses due to both ADF and EAB. ADF is found nearly everywhere in European Russia, from its western borders to the Volga River ${ }^{13}$. EAB has spread over a total area of $150,000 \mathrm{~km}^{2}$ from Moscow outward to eleven other regions of the Russian Federation and is presently moving westward at a rate of $12 \mathrm{~km}$ per year ${ }^{14}$. EAB is predicted to reach Central Europe within 15-20 years ${ }^{4}$. However, in July 2018, active EAB populations were observed in Rossosh region of Voronezh District, about 6 km from Russia's border with Ukraine (unpublished data, Y.N.B.), suggesting that it may be moving faster towards areas with higher-density ash forests.

ADF infection of North American ash species may only be a matter of time. Seven North American ash species already exhibit susceptibility to the fungus ${ }^{14}$. Like EAB in North America, disease impact of ADF will become more pronounced when forest owners accelerate logging of uninfected forests in order to acquire maximum prices for healthy $\operatorname{logs}{ }^{15}$.

Observations in Europe have shown while some trees can withstand the infection of $\mathrm{ADF}^{15}$, far greater losses are to be expected if $\mathrm{EAB}$ meets $\mathrm{ADF}{ }^{4}$. Similarly, ash trees surviving $\mathrm{EAB}$ attacks in North America may be damaged by ADF if the fungal pathogen is introduced there ${ }^{14}$. Now nearly extinct, chestnut and elm forests were lost to two Ascomycete fungal species, namely chestnut blight (Cryphonectria parasitica) and Dutch elm disease (Ophiostoma novoulmi) both of which altered North American forest ecosystems in the early 20th century ${ }^{5}$.

Once invasion of $\mathrm{EAB}$ combines with $\mathrm{ADF}$, ash forests could follow the demise of American chestnut and elm forests. Each pest has its own way of killing ash trees and their combined attack is therefore expected to be more lethal than either of them alone. Even so, loss of ash forests in North America and Eurasia need not to be a foregone conclusion. Policy solutions exist as does scientific intervention. Together these can brought under the aegis of a new international consortium. The best available scientific knowledge for ash forests is now 
abundant yet underutilized. For example, ash species from eastern Asia are more resistant to $\mathrm{EAB}$ and $\mathrm{ADF}$ than other ash species, possibly due to shared co-evolutionary history between the forest species and its attackers ${ }^{4,14}$. Breeding pest resistance is thus feasible as a policy solution.

\section{Policy solutions}

Harmonizing phytosanitary regulations across North America and Eurasia could slow entry of $\mathrm{EAB}, \mathrm{ADF}$ and other pests of Fraxinus species. Although regulations are in place to prevent the introduction and spread of forest pests via transport and trade (see reference ${ }^{16}$ ), they should be continuously updated with science-based knowledge.

In North America, both EAB and ADF appear in the Phytosanitary Alert System of North American Plant Protection Organization (NAPPO) (www.pestalert.org), but ADF exists only as an emerging pathogen because it is not yet present in North America. Here, classifying ADF as a "regulated pest" could help preventing the introduction of ADF into North America.

In Europe, EAB is listed in the A2 List of the European Plant Protection Organization (EPPO) for pests recommended for regulation (www.eppo.int). Previously, ADF was also in the A1 List but has not been contained and the pathogen has already spread across Europe. Our concern is that current legislation is insufficient to prevent invasion, establishment and spread of other non-indigenous pests within the European Union unless general pathways of introductions are controlled earlier along with earlier professional and public engagement ${ }^{17}$. Treating the European Union as a single biosecurity unit with a stricter regulation may also slow spread of future invasive alien species.

In the Eurasian Economic Union (EAEU) countries, ADF should be re-classified as an A2 species. Although ADF is present in Russia, it is currently listed only as an A1 species that is absent in the EAEU (https://vniikr.ru/edinyij-perechen-karantinnyix-obektov-evrazijskogoekonomicheskogo-soyuza, accessed September 8, 2018). EAB is on the joint A2 List for Russia 
othe

countries

in

EAEU,

except

Kazakhstan

(https://gd.eppo.int/taxon/AGRLPL/categorization, accessed September 8, 2018).

Professional awareness is also a necessary complement to better phytosanitary regulations.

Low professional awareness is apparent from a survey conducted in nine European countries with 392 tree professionals ${ }^{18}$. Many lacked awareness or knowledge about either EAB (64.9\%) or ADF $(40 \%)^{18}$. Raising awareness can be an effective intervention strategy: wood packaging material infestation rates in the United States dropped by $36-52 \%$ after International Standards for Phytosanitary Measures No. 15 (ISPM 15) came into force, leading to better inspection and treatment of wood packaging materials ${ }^{19}$.

A related problem is that specific phytosanitary action against a particular organism often takes place after its entry has already occurred. The World Trade Organization (WTO) facilitates international trade so a pest is sometimes banned only after proven economic damage $^{17}$. In such cases, intervention could occur too late. The better course of action is to be proactive. One option is for phytosanitary inspectors to implement the rapid molecular diagnosis kits already available for $\mathrm{ADF}^{20}$. This kit can be integrated with other best practices in phytosanitary regulations harmonized across North America and Eurasia.

\section{Scientific solutions}

\section{Using biological control agents against EAB}

Biological controls can be effective yet have unpredictable outcomes. To date, classical biological control methods are viewed as successful for EAB control in North America ${ }^{5}$. For example, Hymenoptera insects parasitic to EAB were previously introduced from East Asia as control agents. Although these EAB parasites failed to protect mature ash trees, they did enhance saplings' survival and promoted some recovery of the ash in southern Michigan ${ }^{21}$. However, this was not the outcome for the Moscow region, the epicenter of the EAB secondary range in Europe; here the EAB invader populations collapsed due to the polyphagous parasite 
Spathius polonicus Niezabitowski ${ }^{4}$. Spathius polonicus is indigenous to Western Europe and may have reduced outbreak incidence once it spread to the central distribution of European $a^{22}$. This observation calls for studying interacting population dynamics of host and parasite across national borders. To study this, research co-ordination would be essential.

\section{Rapid resistance breeding coupled with phenotype-based methods}

The good news is that European ash species show high genetic variation in ADF resistance ${ }^{15}$ and so ADF resistance is currently being identified in a range of genetic backgrounds using both field-testing and genome- and transcriptome-wide screening of European ash. A population survey of ash trees in Denmark showed ADF tolerance can be screened using single nucleotide polymorphisms (SNPs) and gene expression markers ${ }^{23,24}$. Even so, further research is necessary to identify a large set of reliable SNP markers and these markers must be tested on phenotyped trees across Europe before rapid screening can become operational, and this too requires international cooperation. Identification of resistance mechanisms European ash will provide new insights and better policy solutions.

A related point is that seeds and pollen of European ash spread rapidly across landscapes ${ }^{25}$ and this allows for the identification of more ADF resistant trees. Both newly established and old-growth forests may be protected by combined natural and artificial selection if ash phenotypes selected for high resistance spread their alleles into naturally occurring ash forests. Resistance breeding for ash trees is ongoing in both North America and Europe ${ }^{15,26}$, but molecular shortcuts are essential because they save time ${ }^{24}$.

Research continues towards characterizing susceptibility of different ash species to either EAB or ADF or to both pests. Although studies in Europe show that $F$. americana and $F$. pennsylvanica are susceptible to $\mathrm{ADF}^{14}$ and observations from Russia show that $F$. excelsior are infested by $\mathrm{EAB}^{22}$, there seem to be variation among species. Establishing experimental plots is a necessary action step. Ideal phenotypic candidates are those selected from ash 
populations in the territory of European Russia, which already have both EAB and ADF. Doing so would provide timely insights into resistance in European ash forests for both EAB and ADF.

\section{Understanding dynamics, co-evolution and adaptation of the ash trees in natural forests}

Emerging infectious diseases often leave a fraction of surviving trees and these survivors are critical to the future of the species ${ }^{27}$. It is important to quantify the presence of resistant phenotypes and to assess their fitness under in situ conditions. For ADF, the presence of naturally-occurring genetic resistance has been based on field-testing of survival and crown damage but doing this is only a part of measuring fitness ${ }^{28}$. The potential recovery of ash species in forest ecosystems will also depend on: (a) reproductive success of surviving trees; (b) extent of gene flow among populations; and (c) how the disease influences relative competitiveness with other species in ecosystems. Such studies are complex to conduct under heterogeneous in situ field environments and require cooperation across genetics, ecology and silviculture. Application of DNA markers is another tool which allows precise paternity assignment even in naturally-occurring forests ${ }^{25}$. These markers can also reveal signatures of past and on-going natural selection which is also critical for guiding management of infected ash forests.

\section{Genomics platforms screened for resistance}

Another powerful scientific resource is the reference genome sequence of $F$. excelsior recently published to facilitate studies on ADF resistance ${ }^{24}$. Metabolomic analyses found low levels of iridoid glycoside to be closely associated with ADF resistance in F. excelsior ${ }^{24}$, suggesting a likely trade-off between resistance to ADF and to EAB. More testing is still needed. Similarly, defense-related proteins may be involved in EAB resistance in Manchurian ash ${ }^{29}$ and therefore the candidates for screening and comparison among European, Eurasian and North American ash species. Pest resistance may also be identified using the reference transcriptome generated 
for North America's green $\operatorname{ash}^{30}$. However, we note that the reference ash genome does not yet lead us to markers for EAB resistance.

Taken all together, the best available scientific knowledge includes a wide portfolio of intervention options ranging from comparative genomics, transcriptomics and metabolomics platforms to field testing. More research is required to identify ash genotypes possessing both ADF- and EAB-resistance and the tools are available. The best research strategy is to continue to mine resistance genes in the effort to slow ash forest losses in North America and Eurasia.

\section{Needed: an international consortium}

Both policy and science-based intervention options are fragmented. These solutions clearly require international cooperation. Here we recommend an international consortium, would be charged with taking a swift, integrative action to slow loss of ash forests. As such, the consortium would initiate and coordinate activities as follows: (a) harmonize phytosanitary regulations for transport, travel and trade; (b) raise awareness of $\mathrm{ADF}$ and $\mathrm{EAB}$ among professionals and policy leaders in all affected countries; (c) educate officials on use of rapid diagnostic kits and media tools; and (d) the application of the best available scientific resources including mining ash phenotypes for joint $\mathrm{EAB}$ and $\mathrm{ADF}$ disease resistance.

As a start, we propose that the consortium can be organized with stakeholders including governments, nongovernmental organizations and private companies to share knowledge and coordinate international action. The organization could be similar to the European Cooperation in Science and Technology (COST) action known as FRAXBACK where collaborators share knowledge on ADF among scientists and stakeholders in Europe (http://www.cost.eu/COST_Actions/fps/FP1103, accessed on October 8, 2018). However this new consortium should be global in its scope and include ash pests EAB and ADF. The international consortium would have a time-limited charter based on measurable outcomes. The 
international consortium will require multilateral support perhaps best organized under the International Plant Protection Convention (IPPC) treaty.

In summary, we show reliable policy and science-based solutions are at hand. What is lacking is international co-ordination. Now is the time to act swiftly and save the world's ash forests.

\section{Acknowledgements}

The authors thank Dr. Irina Danilova (Sukachev Institute of Forest of the Siberian Branch of the Russian Academy of Sciences, Krasnoyarsk, Russian Federation) for help with generating the distribution maps and Dr. Andrei D. Orlinski (Scientific Officer, European and Mediterranean Plant Protection Organization, Paris, France) for help with improving the manuscript. D.S.C. was supported by the European Commission under the Forest and Nature for Society (FONASO) Erasmus Mundus Joint Doctorate Program. Y.N.B. was supported by the Russian Foundation for Basic Research (\#17-04-01486a). E.D.K. was supported by the Villum Foundation grant (Grant No. VKR023062).

\section{References}

1. Wallander, E. Belgische Dendrol. Belge 2012, 39-58 (2012).

2. Kovacs, K. F. et al. Ecol. Econ. 69, 569-78 (2010).

3. Siegert, N. W., McCullough, D. G., Liebhold, A. M. \& Telewski F. W. Divers. Distrib. 20(7), 847-58 (2014).

4. Musolin, D. L., Selikhovkin, A. V., Shabunin, D. A., Zviagintsev, V. B. \& Baranchikov Y. N. Baltic For. 23(1), 316-33 (2017).

5. Herms, D. A. \& McCullough, D. G. Annu. Rev. Entomol. 59, 13-30 (2014).

6. Sydnor, T. D., Bumgardner, M. \& Subburayalu, S. Arboric. Urban For. 37(2), 84-9 (2011).

7. Aukema, J. E. et al. PLoS One 6(9), e24587 (2011). 
259

260

261

262

263

264

265

266

267

268

269

270

271

272

273

274

275

276

277

278

279

280

281

282

283

284

8. FAO. Statistical Pocketbook 2015 - World Food and Agriculture. 236 p. (Food and Agriculture Organization of the United Nations, Rome, Italy, 2015). [Accessed on 20.04.2017 at http://www.fao.org/3/a-i4691e.pdf]

9. Bray, A. M. et al. Biol. Invasions 13(12), 2869-87 (2011).

10. Drenkhan, R., Sander, H. \& Hanso, M. Eur. J. Forest Res. 133(5), 769-81 (2014).

11. Pautasso, M., Aas, G., Queloz, V. \& Holdenrieder, O. Biol. Conserv. 158, 37-49 (2013).

12. Husson, C., Cael, O., Grandjean, J. P., Nageleisen, L. M. \& Marcais, B. Plant Pathol. 61(5), 889-95 (2012).

13. Zviagintsev, V., Seraya, L., Panteleev, S., Yaruk, A. \& Baranchikov Y. Hymenoscyphus fraxineus at eastern border of its secondary range in Europe (IUFRO17-1987). In Interconnecting Forests, Science and People: Abstract book. P. 334 (IUFRO 125th Anniversary Congress 2017, Baden-Württemberg: FVA, 2017). [ISBN 978-3-902762-887]

14. Nielsen, L. R., McKinney, L. V., Hietala, A. M. \& Kjær E. D. Eur. J. Forest Res. 136, 15 (2017).

15. McKinney, L. V. et al. Plant Pathol. 63(3), 485-99 (2014).

16. Mackay, H., Keskitalo, E. C. H. \& Pettersson, M. Biol. Invasions 19(7), 1953-70 (2017).

17. Klapwijk, M. J. et al. Ambio. 45(2), 223-34 (2016).

18. Marzano, M. et al. Forest Policy Econ. 70, 164-71 (2016).

19. Haack, R. A. et al. PLoS One 9(5), e96611 (2014).

20. Harrison, C., Tomlinson, J., Ostoja-Starzewska, S. \& Boonham N. Eur. J. Plant Pathol. 149(2), 253-59 (2017).

21. Duan, J., Bauer, L. \& Van Driesche, R. Forest Ecol. Manag. 394, 64-72 (2017).

22. Orlova-Bienkowskaja, M. J. Eur. J. Entomol. 112(4), 778-89 (2015).

23. Harper, A. L. et al. Sci. Rep. 6, 19335 (2016).

24. Sollars, E. S. et al. Nature 541(7636), 212-6 (2017). 
25. Semizer-Cuming, D., Kjær, E. D. \& Finkeldey, R. PloS One 12(10), e0186757 (2017).

26. Koch, J. L. et al. Breeding strategies for the development of emerald ash borer-resistant North American ash. In Proceedings of the Fourth International Workshop on the Genetics of Host-Parasite Interactions in Forestry: Disease and Insect Resistance in Forest Trees. (Gen. Tech. Rep. PSW-GTR-240) 372 p. (Pacific Southwest Research Station, Forest Service, U.S. Department of Agriculture, Albany, CA, 2012).

27. Budde, K. B., Nielsen, L. R., Ravn, H. P. \& Kjær, E. D. Current Forestry Rep. 2(1), 18 29 (2016).

28. Kjær, E. D., McKinney, L. V., Nielsen, L. R., Hansen, L. N. \& Hansen J. K. Evol. Appl. 5(3), 219-28 (2012).

29. Rigsby, C. M., Herms, D. A., Bonello, P. \& Cipollini D. J. Chem. Ecol. 42(8), 782-92 (2016).

30. Lane, T. et al. BMC Genomics 17(1), 702 (2016). 
299 with author's permission: Wallander, E. Belgische Dendrol. Belge 2012, 39-58 (2012).

\begin{tabular}{|c|c|}
\hline Sections and Species & Geographic Range \\
\hline \multicolumn{2}{|l|}{ Section: Dipetalae } \\
\hline F. anomala & SW USA, C Mexico \\
\hline F. dipetala & SW USA, NW Mexico \\
\hline F. quadrangulata & C \& E USA, C Canada \\
\hline \multicolumn{2}{|l|}{ Section: Fraxinus } \\
\hline F. angustifolia subsp. angustifolia & SW Europe, NW Africa \\
\hline F. angustifolia subsp. oxycarpa & SE Europe, C Europe \\
\hline F. angustifolia subsp. syriaca & Turkey to Central Asia \\
\hline F. excelsior & N \& C Europe to W Russia, around Black Sea \\
\hline F. mandshurica & China, Japan, Korea, E Russia \\
\hline F. nigra & E USA, SE Canada \\
\hline \multicolumn{2}{|l|}{ Section: Meloides } \\
\hline F. albicans & SW USA (Texas, Oklahoma), N Mexico \\
\hline F. americana & E USA \& SE Canada \\
\hline F. berlandieriana & SW USA, NE, C \& E Mexico \\
\hline F. biltmoreana & E USA \\
\hline F. caroliniana & SE USA \\
\hline F. coriacea & SW USA, NW Mexico \\
\hline F. cubensis & SE USA (S Florida), Cuba \\
\hline F. latifolia & W USA, SW Canada \\
\hline F. papillosa & SW USA, N Mexico \\
\hline F. pauciflora & SE USA \\
\hline F. pennsylvanica & C \& E USA, S Canada \\
\hline F. profunda & E USA, Canada \\
\hline F. smallii & E USA \\
\hline F. uhdei & C America, Hawaii, cultivated \\
\hline F. velutina & SW USA, N \& C Mexico \\
\hline \multicolumn{2}{|l|}{ Section: Ornus } \\
\hline F. apertisquamifera & Japan \\
\hline F. baroniana & China \\
\hline F. bungeana & China \\
\hline F. chinensis subsp. chinensis & China, Korea, Vietnam, Thailand \\
\hline F. chinensis subsp. rhynchophylla & N China, Korea, Japan, SE Russia \\
\hline F. floribunda & Afghanistan through Himalaya to SE Asia \\
\hline F. griffithii & SE Asia \\
\hline F. hopeiensis & China \\
\hline F. lanuginosa & Japan \\
\hline F. longicuspis & Japan \\
\hline F. malacophylla & China, Thailand \\
\hline F. micrantha & Himalaya \\
\hline F. ornus & C \& E Mediterranean, SW Asia \\
\hline F. paxiana & Himalaya, China \\
\hline F. raibocarpa & C Asia \\
\hline F. sieboldiana & China, Japan, Korea \\
\hline F. trifoliolata & China \\
\hline \multicolumn{2}{|l|}{ Section: Pauciflorae } \\
\hline F. dubia & E Mexico, Guatemala \\
\hline F. gooddingii & SW USA (Arizona), N Mexico (Sonora) \\
\hline F. greggii & SW USA (Texas), NE \& C Mexico \\
\hline F. purpusii & NE \& C Mexico, Guatemala \\
\hline F. rufescens & C Mexico \\
\hline \multicolumn{2}{|l|}{ Section: Sciadanthus } \\
\hline F. hubeiensis & China \\
\hline F. xanthoxyloides & NW Africa, Himalaya \\
\hline \multicolumn{2}{|l|}{ Incertae sedis } \\
\hline F. cuspidata & SW USA, N Mexico \\
\hline
\end{tabular}


F. chiisanensis

F. platypoda
Korea

China, Japan 